\title{
Novel Gaseous Ethylene Binding Inhibitor Prevents Ethylene Effects in Potted Flowering Plants
}

\author{
Margrethe Serek ${ }^{1}$ \\ Department of Environmental Horticulture, University of California, Davis, CA 95616 \\ Edward C. Sisler \\ Department of Biochemistry, North Carolina State University, Raleigh, NC 27695 \\ Michael S. Reid \\ Department of Environmental Horticulture, University of California, Davis, CA 95616
}

Additional index words. abscission, begonia, DACP, ethylene binding, flower senescence, kalanchoe, 1-MCP, 1-methylcyclopropene, rosa, SIS-X, STS

\begin{abstract}
A 6-hour fumigation of flowering Begonia $\times$ elatior hybrida Fotsch. 'Najada' and 'Rosa', B. ×tuberhybrida Voss. 'Non-Stop', Kalanchoe blossfeldiana Poelln. 'Tropicana', and Rosa hybrida L. 'Victory Parade' plants with 1-MCP, (formerly designated as SIS-X), a gaseous nonreversible ethylene binding inhibitor, strongly inhibited exogenous ethylene effects such as bud and flower drop, leaf abscission, and accelerated flower senescence. The inhibitory effects of 1-MCP increased linearly with concentration, and at $20 \mathrm{nl}^{-l i t e r^{-1}}$ this compound gave equal protection to that afforded by spraying the plants with a 0.5 STS mm solution. Chemical names used: 1-methylcyclopropene (1-MCP), silver thiosulfate (STS).
\end{abstract}

The spectacular effects of STS in overcoming the deleterious effects of ethylene in potted flowering plants (Cameron and Reid, 1981) have led to widespread commercial use of this chemical (Veen, 1983). Because STS contains silver, which is seen as a potential environmental pollutant, its use for potted flowering plants has been restricted in some countries (Serek and Reid, 1993). Researchers have therefore been searching for alternative strategies for preventing ethylene damage in potted plants, including using ethylene biosynthesis and binding inhibitors (Serek et al., 1994). In studies examining the nature of ethylene binding and of the binding site, Sisler and Blankenship (1993) and Sisler et al. $(1986,1993)$ found that certain ethylene analogues inhibited its binding. A cyclic di-olefin (2,5-norbornadiene) strongly inhibited binding and prevented the effects of ethylene (Sisler et al., 1986). Because the binding was reversible, the effects were not permanent. A diazo derivative [diazocyclopentadiene (DACP)] was synthesized as a potential photoaffinity label for the ethylene binding site (Sisler and Blankenship, 1993; Sisler et al., 1993). DACP also inhibited ethylene binding, but the inhibition was irreversible, probably because DACP covalently attached to the binding site when the diazo group decomposed (Serek et al., 1994). Although the effects of this compound are interesting to horticulturists, its lability and explosiveness make it an unlikely candidate for commercial application.

A new gaseous binding-site competitor (1-MCP) has substantially improved properties over DACP. In model systems, this material, a nontoxic and relatively simple organic compound, inhibits ethylene action when plants are treated at concentrations as low as $0.5 \mathrm{nl} \cdot$ liter $^{-1}$ (E.C. Sisler, unpublished data). We report

Received for publication 30 Dec. 1993. Accepted for publication 23 May 1994. We thank the late Jackson F. Hills for advice on data analysis and Nurserymen's Exchange, Half Moon Bay, and Golden State, Watsonville, Calif., for kindly supplying the plants. The experiments were supported by a grant from the Danish Agricultural and Veterinary Research Council (grant no. 13-4549) and supplementary grants from the Foundation of Hofmansgave, the Foundation of Ib Henriksen and the Carlsberg Foundation (MS). The cost of publishing this paper was defrayed in part by the payment of page charges. Under postal regulations, this paper therefore must be hereby marked advertisement solely to indicate this fact.

${ }^{1}$ On leave from The Royal Veterinary and Agricultural Univ., Dept. of Agricultural Sciences, Section for Horticulture, Rolighedsvej 23, 1958 Frederiksberg C., Denmark. To whom reprint requests should be addressed. here the results of tests of the efficacy of 1-MCP in preventing ethylene effects on the display quality and shelf life of potted flowering plants.

\section{Materials and Methods}

Plant material. Potted plants were obtained from commercial growers at the bud stage and transported to Univ. of California, Davis. The plants tested were Begonia $\times$ elatior hybrida 'Najada' and 'Rosa', B. ×tuberhybrida 'Non-Stop', Kalanchoe blossfeldiana 'Tropicana', and Rosa hybrida 'Victory Parade'.

The plants were grown to commercial maturity in the university's experimental greenhouses under the following conditions: 22/ $18 \mathrm{C}, 70 \%$ relative humidity $(\mathrm{RH})$, and $1100 \mu \mathrm{mol} \cdot \mathrm{m}^{-2} \cdot \mathrm{s}^{-1}$ natural daylight for $10 \mathrm{~h} /$ day.

1-MCP treatment. Plants were placed in sealed glass chambers at $20 \mathrm{C}$ and $15 \mu \mathrm{mol} \cdot \mathrm{m}^{-2} \cdot \mathrm{s}^{-1}$ artificial light, and 6- to 20 -nl $\cdot$ liter ${ }^{-1} 1$ MCP (gas phase) aliquots were injected into the glass chambers. The chambers remained sealed for $6 \mathrm{~h}$. Control plants were sealed in air in identical chambers. The plants were exposed to low concentrations of ethylene or placed in an interior environment [ $21 \mathrm{C}, 60 \% \mathrm{RH}, 12 \mathrm{~h} /$ day of light $\left(15 \mu \mathrm{mol} \cdot \mathrm{m}^{-2} \cdot \mathrm{s}^{-1}\right)$ from cool-white fluorescent tubes] to evaluate commercial shelf life.

STS treatment. Plants were sprayed to runoff $(25 \mathrm{ml} /$ plant $)$ with a $0.5 \mathrm{~mm}$ STS solution (Argylene, Denmark).

Ethylene treatment. Treated and control plants were enclosed in glass chambers ventilated ( 40 liters $\cdot \mathrm{h}^{-1}$ ) with air containing ethylene at 0.4 or $1.0 \mu \mathrm{l} \cdot$ liter $^{-1}$. The ethylene concentration was monitored daily by gas chromatography. The number of senescent flowers and loss of buds, flowers, and leaves from the plants were recorded daily. To examine the nature of the inhibitory action of 1MCP, B. ×tuberhybrida. 'Non-Stop' plants treated with 1-MCP (5 nl-liter ${ }^{-1}$ ) were placed in similar glass chambers ventilated with various $\left(0,0.25,0.5,1\right.$, and $1.4 \mu 1 \cdot$ liter $\left.^{-1}\right)$ concentrations of ethylene gas. Bud and flower drop were recorded daily.

Binding measurements. Binding was measured as previously described (Serek et al., 1994). Petals were removed from the plant and allowed to stand overnight to allow wound ethylene to subside. Binding was carried out on 2-g petals of $R$. hybrida 'Victory Parade'. The petals were exposed to $0.5 \mu \mathrm{Ci}$ of ${ }^{14} \mathrm{C}$-ethylene and 1- 
MCP in 2.5-liter desiccators for $0.75 \mathrm{~h}$. They were ventilated (45 sec) and placed in 250-ml jars with a vial containing $0.3 \mathrm{ml}$ mercury perchlorate on a piece of fiberglass filter to increase the surface area. After $\approx 12 \mathrm{~h}$, the vials were removed, scintillation fluid was added, and the radioactivity was determined.

Binding constants. Binding constants were determined by measuring competition between $1-\mathrm{MCP}$ and ${ }^{14} \mathrm{C}$-ethylene. Values were obtained from Scatchard plots and corrected for the presence of ethylene by the methods of Cheng and Prusoff (1973) and Prescan et al. (1989).

Experimental design and statistics. The experiments were conducted in a randomized complete-block design, using a minimum of five replicate plants per treatment. Statistical procedures were performed using the PC-SAS software package. Differences between means were determined using orthogonal comparisons or Student's $t$ test.

\section{Results}

Effects of 1-MCP on postharvest quality of potted flowering plants Display life. In the interior environment, B. ×elatior hybrida 'Najada' and 'Rosa', R. hybrida, 'Victory Parade', and $K$. blossfeldiana 'Tropicana' had an excellent display life regardless of treatment (Table 1). After several weeks, sudden abscission of leaves and buds from $R$. hybrida plants marked the end of useful display life in the controls; plants treated with STS or 1-MCP lasted $\approx 10$ days longer. When the treated plants were challenged by exposure to $1 \mu \mathrm{l} \cdot$ liter $^{-1}$ ethylene, their lives were much shorter. Control plants lost quality very rapidly (Table 1) through ethylenestimulated abscission of leaves or buds (roses) or senescence (kalanchoe) and abscission of mature flowers (begonia) (Fig. 1). Plants treated with STS or 1-MCP retained their leaves, buds, and flowers and had a display life up to 14 times that of the untreated controls (Table 1, Fig. 2). The effects of 1-MCP in preventing bud and flower drop were not significantly different from those of STS (Fig. 2).

Bud, flower, and leaf drop. The nature of the relationship between 1-MCP treatment concentration and time in ethylene on ethylene-induced bud and flower drop in B. Xelatior hybrida 'Najada' is shown in Fig. 3. Increasing the 1-MCP concentration from 0 to $6 \mathrm{nl} \cdot$ liter $^{-1}$ reduced the ethylene response quadratically, while there was an overall linear relationship between time and loss of buds and flowers. Leaf loss from $R$. hybrida 'Victory Parade' followed slightly different kinetics, being essentially a flat

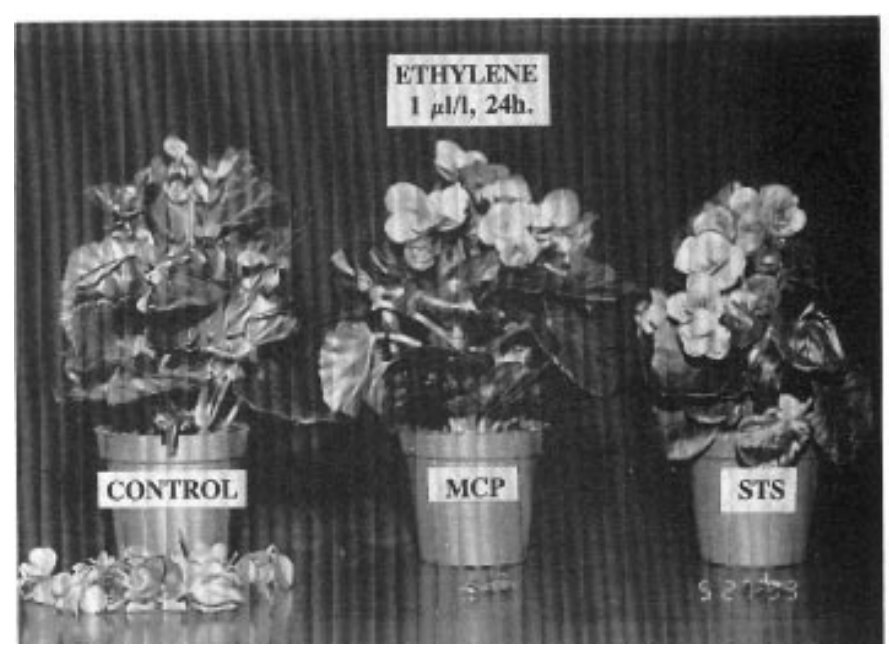

Fig. 1. Bud and flower drop of Begonia $\times$ elatior hybrida 'Rosa' pretreated with 5 nl-liter ${ }^{-1}$ 1-MCP (6 h), 0.5 mm STS, or nontreated (control) after exposure for 1 day to $1 \mu \mathrm{l} \cdot$ liter $^{-1}$ ethylene.

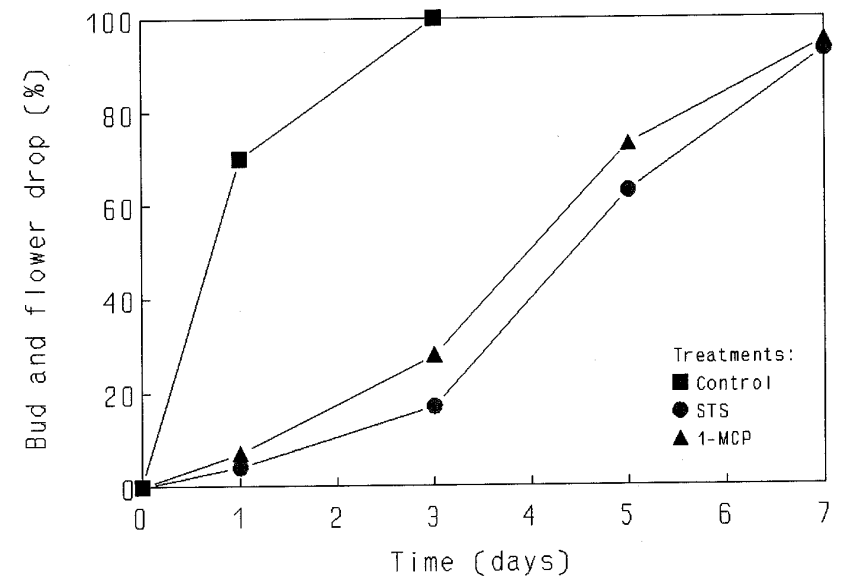

Fig. 2. Ethylene-stimulated bud and flower drop in Begonia xelatior hybrida 'Rosa' plants pretreated with $5 \mathrm{nl} \cdot \mathrm{liter}^{-1} 1$-MCP $(6 \mathrm{~h}), 0.5 \mathrm{~mm}$ STS, or nontreated (control). During pretreatment, STS-treated and control plants were placed in air in tanks identical to those used for 1-MCP treatment. After pretreatment, all plants were exposed to $1 \mu \mathrm{l} \cdot$ liter $^{-1}$ ethylene.

Source of variation:

Treatment $\times$ days: $\quad$ Control vs. other $\times \mathrm{L}$ or $\mathrm{Q} \quad \mathrm{L}^{* * *} \mathrm{Q}^{\mathrm{Ns}}$ 1-MCP vs. STS $\times$ L or $Q \quad \mathrm{~L}^{\mathrm{Ns}} \mathrm{Q}^{\mathrm{Ns}}$

$\mathrm{L}=$ linear, $\mathrm{Q}=$ quadratic. ${ }^{\text {Ns,**** }}$ Nonsignificant or significant at $P=0.001$.

Table 1. Display life of Begonia ¥elatior hybrida 'Rosa’ plants pretreated with $5 \mathrm{nl} \cdot$ liter $^{-1} 1-\mathrm{MCP}, 0.5 \mathrm{mM}$ STS, or nontreated and Rosa hybrida 'Victory Parade' and Kalanchoe blossfeldiana 'Tropicana' plants preatreated with $20 \mathrm{nl} \cdot \mathrm{liter}^{-1} 1-\mathrm{MCP}, 0.5 \mathrm{mM}$ STS, or nontreated. Control (nontreated) and STS-treated flowers were placed in air in tanks identical to those used for 1-MCP treatment. After pretreatment, all flowers were exposed to $1 \mu \mathrm{l} \cdot \mathrm{liter}^{-1}$ ethylene or kept in an ethylene-free atmosphere (interior environment room).

\begin{tabular}{lccc}
\hline \hline Species & Treatment & $\begin{array}{c}\text { Display life (days) } \\
\text { ethylene stressed }\end{array}$ & $\begin{array}{c}\text { Interior } \\
\text { environment }\end{array}$ \\
\hline Begonia ×elatior & Control & $2.3 \mathrm{~b}^{\mathrm{z}}$ & $26.2 \mathrm{a}$ \\
& STS & $7.5 \mathrm{a}$ & $28.5 \mathrm{a}$ \\
Rosa hybrida & $1-\mathrm{MCP}$ & $7.3 \mathrm{a}$ & $26.1 \mathrm{a}$ \\
& Control & $3.3 \mathrm{~b}$ & $21.1 \mathrm{a}$ \\
Kalanchoe blossfeldiana & STS & $9.3 \mathrm{a}$ & $31.0 \mathrm{~b}$ \\
& $1-\mathrm{MCP}$ & $9.0 \mathrm{a}$ & $29.5 \mathrm{~b}$ \\
& Control & $2.0 \mathrm{~b}$ & $35.2 \mathrm{a}$ \\
& STS & $14.0 \mathrm{a}$ & $37.1 \mathrm{a}$ \\
& $1-\mathrm{MCP}$ & $13.3 \mathrm{a}$ & $35.5 \mathrm{a}$ \\
\hline
\end{tabular}

${ }^{\mathrm{z}}$ Mean separation within columns at $P=0.05$ according to Student's $t$ test for the hypothesis $\mathrm{H}_{\mathrm{o}}$ : LSM(i) $=\mathrm{LSM}(\mathrm{j})$. 


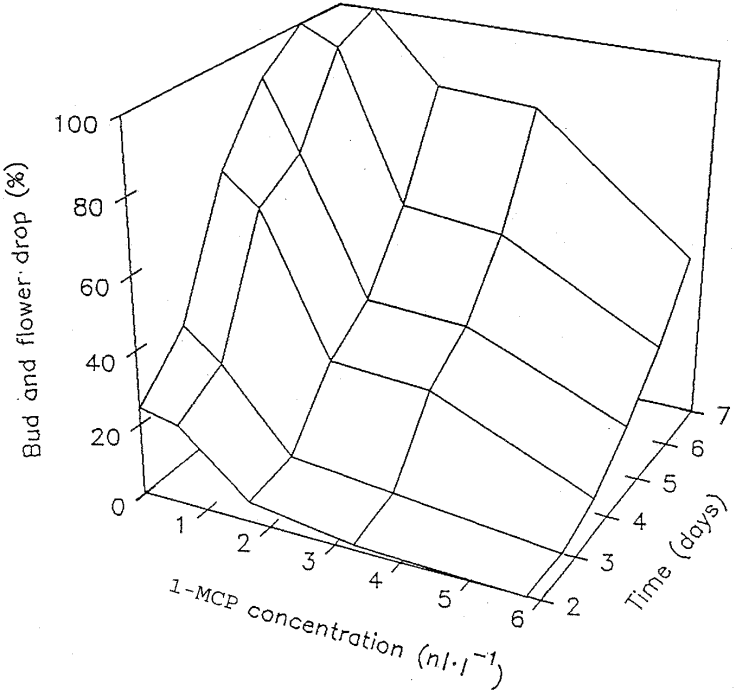

Fig. 3. Ethylene-stimulated bud and flower drop in Begonia Xelatior hybrida 'Najada' plants pretreated with $0,0.6,1.7,3.3$, or $5.8 \mathrm{nl} \cdot$ liter- $^{-1} 1$-MCP $(6 \mathrm{~h})$. Control plants were placed in air in tanks identical to those used for 1-MCP treatment. After treatment, all plants were exposed to $0.4 \mu \mathrm{l} \cdot$ liter $^{-1}$ ethylene. Source of variation:

$\begin{array}{lll}\text { Treatment } \times \text { days: } & \text { Control vs. other } \times \mathrm{L} \text { or } \mathrm{Q} & \mathrm{L}^{\mathrm{ss}} \mathrm{Q}^{* * * *} \\ & \text { Among 1-MCP treatments } \times \mathrm{L} \text { or } \mathrm{Q} & \mathrm{L}^{* * *} \mathrm{Q}^{*}\end{array}$

$\mathrm{L}=$ linear, $\mathrm{Q}=$ quadratic. ${ }^{\mathrm{Ns}, *, * * *}$ Nonsignificant or significant at $P=0.05$ or 0.001 , respectively.

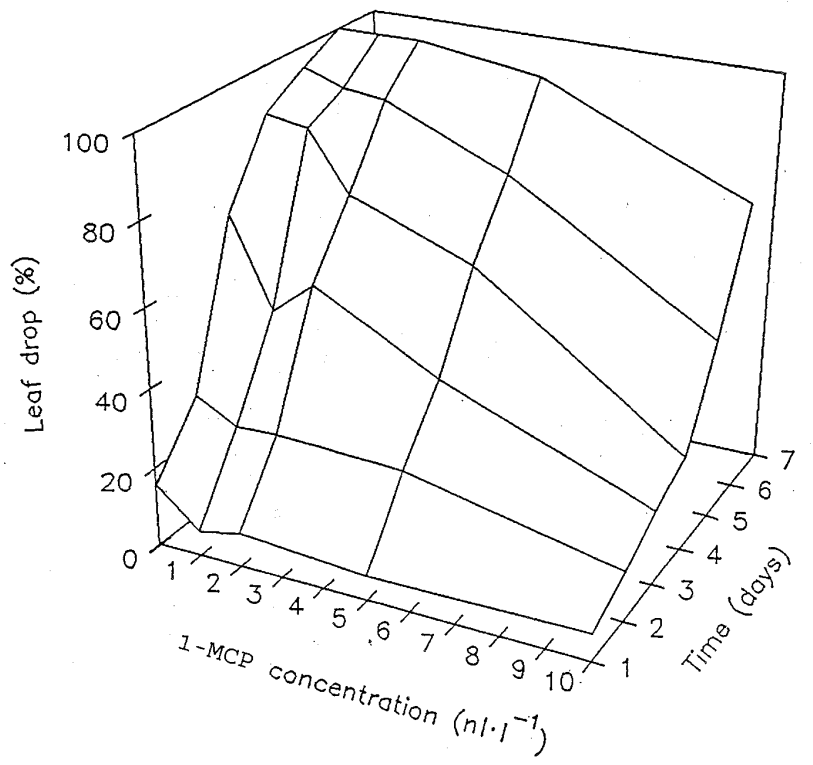

Fig. 4. Ethylene-stimulated leaf drop in Rosa hybrida 'Victory Parade' plants pretreated with $0,1,2,5$, or $10 \mathrm{nl} \cdot \mathrm{liter}^{-1} 1$-MCP $(6 \mathrm{~h})$. Control plants $(0$ $\mathrm{nl} \cdot$ liter $^{-1} 1-\mathrm{MCP}$ ) were placed in air in tanks identical to those used for 1-MCP treatment. After treatment, all plants were exposed to $1 \mu 1 \cdot$ liter $^{-1}$ ethylene. Source of variation:

Treatment $\times$ days:

Control vs. other $\times \mathrm{L}$ or $\mathrm{Q}$

$\mathrm{L}^{* *} \mathrm{Q}^{*}$

Among 1-MCP treatments $\times \mathrm{L}$ or $\mathrm{Q} \quad \mathrm{L}^{* * *} \mathrm{Q}^{\mathrm{N}}$

$\mathrm{L}=$ linear, $\mathrm{Q}=$ quadratic. ${ }^{\mathrm{Ns}, * * *, * * * *}$ Nonsignificant or significant at $P=0.05,0.01$, or 0.001 , respectively.

surface (Fig. 4). The responses to 1-MCP concentration and to treatment time were linear.

Effects of 1-MCP concentration on flower senescence. Kalanchoe blossfeldiana, one of the most ethylene-sensitive potted flowering plants, was used to test the effects of 1-MCP concentration on flower senescence. One day after placing control plants in 1

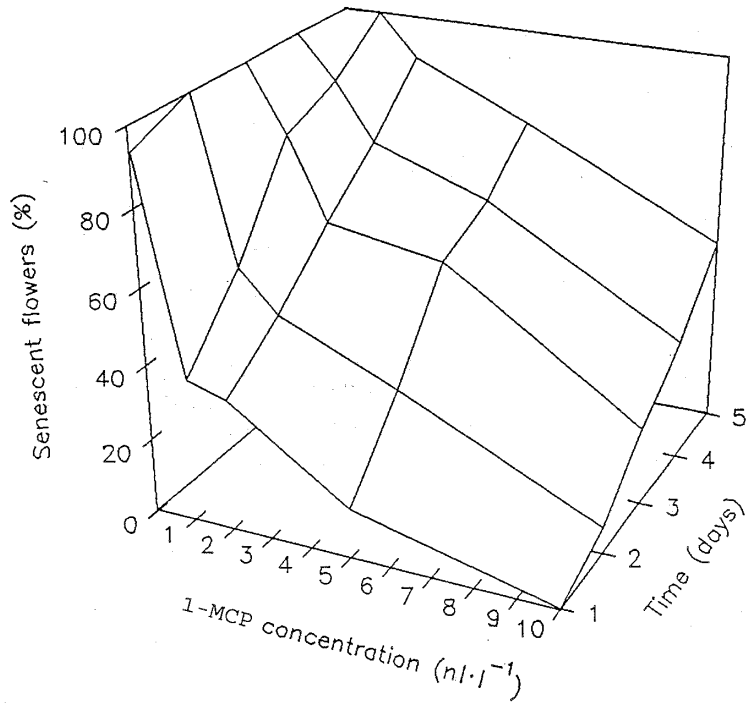

Fig. 5. Ethylene-stimulated flower senescence of Kalanchoe blossfeldiana 'Tropicana' pretreated with $0,1,2,5$, or $10 \mathrm{nl} \cdot \operatorname{liter}^{-1} 1$-MCP $(6 \mathrm{~h})$. Control plants ( $0 \mathrm{nl} \cdot$ liter $^{-1} 1$-MCP) were placed in air, in tanks identical to those used for 1-MCP treatment. After treatment, all plants were exposed to $1 \mu 1 \cdot$ liter $^{-1}$ ethylene for 5 days.

Source of variation:

Treatment $\times$ days:

Control vs. other $\times \mathrm{L}$ or $\mathrm{Q}$

$\mathrm{L}^{* * *} \mathrm{Q}^{\mathrm{NS}}$

Among 1-MCP treatments $\times \mathrm{L}$ or $\mathrm{Q} \quad \mathrm{L}^{\mathrm{Ns}} \mathrm{Q}^{* * *}$

$\mathrm{L}=$ linear, $\mathrm{Q}=$ quadratic. ${ }^{\mathrm{Ns}, * * * * * *}$ Nonsignificant or significant at $P=0.01$ or 0.001 , respectively.

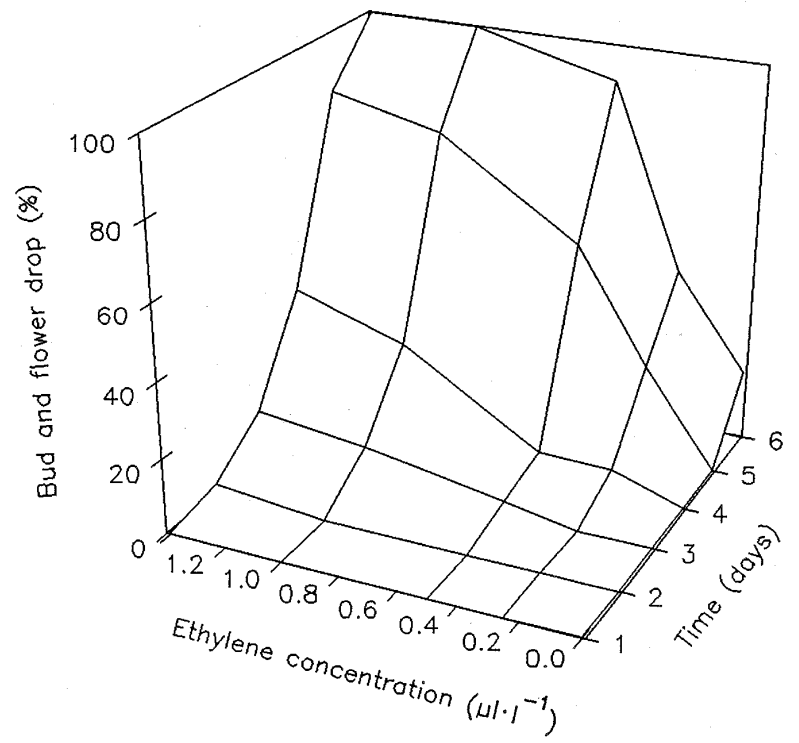

Fig. 6. Ethylene-stimulated bud and flower drop in Begonia ×tuberhybrida 'NonStop' plants pretreated with $5 \mathrm{nl} \cdot$ liter $^{-1} 1$-MCP. After treatment, all plants were exposed to $0,0.25,0.5,1$, or $1.4 \mu \mathrm{l} \cdot$ liter $^{-1}$ ethylene.

Source of variation:

Treatment $\times$ days: $\quad$ Control vs. other $\times \mathrm{L}$ or $\mathrm{Q} \quad \mathrm{L}^{* * *} \mathrm{Q}^{* * * *}$

$\mathrm{L}=$ linear, $\mathrm{Q}=$ quadratic. ${ }^{* * *}$ Significant at $P=0.001$.

Among ethylene concentration $\times \mathrm{L}$ or $\mathrm{Q} \quad \mathrm{L}^{* * *} \mathrm{Q}^{* * * *}$

$\mathrm{L}=$ linear, $\mathrm{Q}=$ quadratic. $\quad$ Significant at $P=0.001$

$\mu 1 \cdot$ liter $^{-1}$ ethylene, their flowers were $95 \%$ senescent (Fig. 5). The percentage of senescent flowers increased linearly with time and decreased quadratically with increasing 1-MCP concentration.

Effects of ethylene concentration. The effects of ethylene concentration on the response of 1-MCP treated plants were tested using $B$. $\times$ tuberhybrida 'Non-Stop' treated with $5 \mathrm{nl} \cdot$ liter $^{-1} 1$-MCP. 


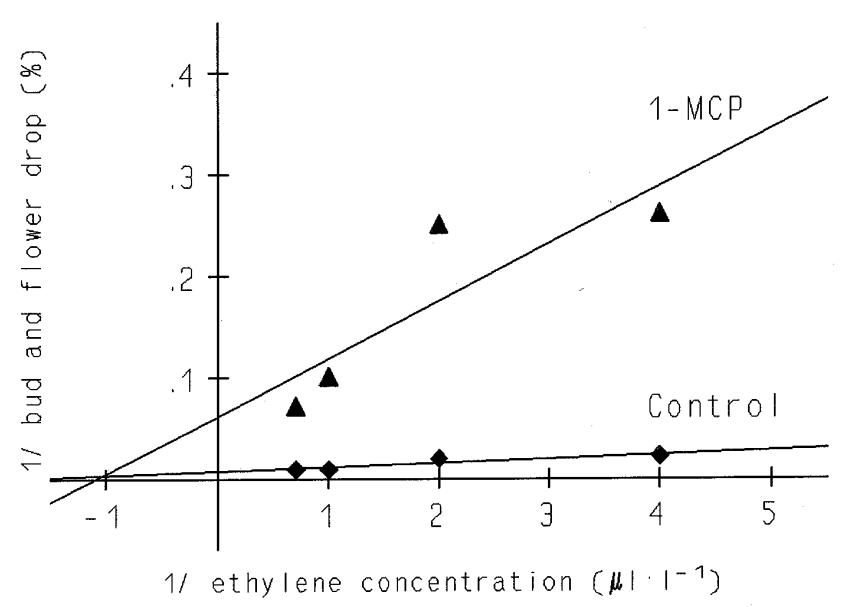

Fig. 7. Double-reciprocal plot of bud and flower drop (\%) in Begonia $\times$ tuberhybrida 'Non-Stop' plants, with or without a $5 \mathrm{nl} \cdot \mathrm{liter}^{-1} 1$-MCP pretreatment, as a function of ethylene concentration (third day).

Table 2. Binding constants for 1-MCP in Rosa hybrida 'Victory Parade'.

\begin{tabular}{lcc}
\hline \hline Species & $\mathrm{C} 50\left(\mathrm{~K}^{\prime} \mathrm{d}\right)\left(\mathrm{nl} \cdot \mathrm{liter}^{-1}\right)$ & $\mathrm{Kd}^{\mathrm{z}}\left(\mathrm{nl} \cdot \mathrm{liter}^{-1}\right)$ \\
\hline Rosa hybrida & 10.6 & 8.0
\end{tabular}

$\overline{{ }^{\mathrm{Z}} \mathrm{Kd}}$ is calculated from $\mathrm{K}$ ' $\mathrm{d}$ using the formula $\mathrm{K}$ 'd $=\mathrm{Kd}(1+\mathrm{S} / \mathrm{Ks})$, where $\mathrm{S}$ and $\mathrm{Ks}$ refer to the concentration and dissociation constants for ethylene.

Bud and flower drop in response to increasing ethylene concentrations showed a strong quadratic trend, mirrored in the response surface (Fig. 6). A double-reciprocal plot of the effects of ethylene concentration on bud and flower drop of control and 1MCP-treated begonia plants (Fig. 7) suggests a noncompetitive inhibition (the lines intersect close to the $\mathrm{x}$ axis).

Binding constants. Binding constants are the first direct measurements of the effect of the concentration of a compound that interacts permanently with the ethylene binding components (Table 2). Although the values obtained are not strictly valid from a kinetic standpoint because the reaction is not reversible (or is extremely slow), they are obtained in competition with ethylene. Since the treatment time used was minimal, they should approximate the correct value. The values show that only very low amounts of 1-MCP are needed to inactivate the receptor. These concentrations are higher than the minimum required for a physiological effect in the absence of ethylene competition. DACP shows similar kinetics, but, with DACP, the measurements (Serek et al., 1994) are based on the original compound (DACP) rather than the active component and are therefore much higher. The active DACP photolysis product would probably act at a concentration close to that found for 1-MCP.

\section{Discussion}

The dramatic inhibition of the deleterious effects of ethylene in potted plants by 1-MCP pretreatment indicate that this compound, if registered, may be the STS substitute the ornamentals industry has been seeking (Nell, 1992). At minute concentrations $\left(20 \mathrm{nl} \cdot\right.$ liter $\left.^{-1}\right), 1-\mathrm{MCP}$ provided as much protection as STS (Table 1), preventing ethylene-induced bud and flower abscission (Fig. 3), leaf abscission (Fig. 4), and flower senescence (Fig. 5). Because the concentration required is so small, commercial application could be in the greenhouse before packing, in the transportation vehicle, or in a storage area. STS is effective usually at close to the concentration at which it causes phytotoxicity (Cameron and Reid, 1981). We observed no phytotoxic symptoms of $1-\mathrm{MCP}$, even at $20 \mathrm{nl} \cdot \mathrm{liter}^{-1}$. It would be interesting to see if even greater protection could be obtained at higher concentrations.

The very low binding constant $\left(\mathrm{K}_{\mathrm{d}}=8 \mathrm{nl} \cdot \mathrm{liter}^{-1}\right)$ obtained in competition assays between 1-MCP and ethylene indicates the effectiveness with which this compound inhibits ethylene action. Of course, the binding constant represents the binding of petal receptors rather than those that are probably involved in the physiological processes examined here-the cells of the petal and pedicel abscission zones. Nevertheless, the data indicate the very effective binding of 1-MCP to the ethylene receptor. The double- reciprocal plot (Fig. 7) of the effects of different ethylene concentrations on bud and flower drop in control and treated plants suggests a noncompetitive inhibition, a result consistent with the hypothesis that 1-MCP binds irreversibly to the ethylene binding site.

\section{Literature Cited}

Cameron, A.C. and M.S. Reid. 1981. The use of silver anionic complex as a foliar spray to prevent flower abscission of Zygocactus. HortScience 16:761-762.

Cheng, Y. and W.H. Prusoff. 1973. Relationship between the inhibitor constant (Ki) and the concentration of inhibitor which causes $50 \%$ inhibition (I50) of an enzymatic reaction. Biochem. Pharmacol. 22:30993108.

Nell, T.A. 1992. Taking silver safely out of the longevity picture. Grower Talks June:35-38.

Prescan, E., H. Porumb, and I. Lascu. 1989. Potential misinterpretation of competitive binding assays. Trends in Biochem. Sci. 14:443-444.

Serek, M. and M.S. Reid. 1993. Anti-ethylene treatments for potted flowering plants-Relative efficacy of inhibitors of ethylene action and biosynthesis. HortScience 28:1180-1181.

Serek, M., E.C. Sisler, and M.S. Reid. 1994. A volatile ethylene inhibitor improves the postharvest life of potted roses. J. Amer. Soc. Hort. Sci. 119:572-577.

Sisler, E.C., M.S. Reid, and S.F. Yang. 1986. Effect of antagonists of ethylene action on binding of ethylene in cut carnations. Plant Growth Regulat. 4:213-218.

Sisler, E.C. and S.M. Blankenship. 1993. Diazocyclopentadiene, a light sensitive reagent for the ethylene receptor. Plant Growth Regulat. 12:125-132.

Sisler, E.C., S.M. Blankenship, M. Fearn, C. Jeffrey, and R. Hanes. 1993. Effect of Diazocyclopentadiene (DACP) on cut carnations, p. 182-187. In: J.C. Pech, A. Latche, and C. Balaque (eds.). Cellular and molecular aspects of the plant hormone ethylene. Kluwer Academic Publishers, Dordrecht, The Netherlands.

Veen, H. 1983. Silver thiosulfate: An experimental tool in plant science. Scientia Hort. 181:155-160. 